\title{
Meme kanseri trucut iğne biyopsi ve rezeksiyon materyallerinde yeni moleküler sınıflama, tanı ve hormon reseptörlerinin durumu tutarlı mı?
}

\author{
Are the new molecular classification, diagnosis and status of hormone receptors \\ compatible between core needle biopsy and surgical specimen in breast cancer?
}

Yeliz Arman Karakaya, Sevda Yılmaz, Hande Karabaş

\section{Öz}

Amaç: Meme kanserinde, trucut iğne biyopsi (TiB) ve rezeksiyon materyalleri arasında, tanısal uyum, histolojik derece, moleküler alt tipleri, östrojen reseptörü (ER), progesteron reseptörü $(P g R)$ ve insan epidermal büyüme faktörü reseptörü 2 (HER2) düzeylerinin karşılaştırılarak sonuçların literatür eşliğinde değerlendirilmesi amaçlanmıştır.

Gereç ve yöntem: 2018 Mayıs-2020 Kasım tarihleri arasında, Pamukkale Üniversitesi Tıp Fakültesi Patoloji Anabilim Dalı'nda tanı almış 64 olguya ait TỉB ve aynı hastaların rezeksiyon materyalleri çalışmaya alınmıştır. Tümör tipi, derecesi, moleküler alt tipleri ve immunohistokimyasal olarak ER, PgR, HER2, Ki-67 ve moleküler FISH yöntemi ile HER2 durumuna ait patolojik bilgiler retrospektif olarak incelenmiştir.

Bulgular: TiB ile rezeksiyon materyallerinin histolojik tipi arasındaki uyum oranı \%93,75'tir. ER, PgR, HER2 uyum oranları sırasıyla, \%89 (kappa, 0,685, p<0,001), \%81,8 (kappa, 0,645, p<0,001), \%95 (kappa=8,68, $p<0,001$ )'tir. HER2 uyum oranı, ER ve PgR reseptör uyum oranına göre daha iyidir. Ki-67'ye baktığımızda \%79 oranında, orta düzeyde uyum (kappa, 0,447, p<0,001) görülmüştür. Derece karşılaştırmasında \%79 uyum oranı ile iyi uyum (kappa, 0,637, $p<0,001$ ) bulunmuştur. Moleküler sınıflama arasında uyum oranı \%93 olup, çok iyi uyum (kappa, 0,882, $p<0,001$ ) bulunmuştur. Lüminal $A$ en fazla görülen tip olup, uyum oranı \%97'tür.

Sonuç: Tanısal biyopsi ve rezeksiyon materyalleri arasında yüksek oranda uyum görülmüştür. TíB'lerin tümörün histopatolojik özelliklerinin belirlenmesi, tanı, tedavi ve prognozda önemi olan ER, PgR, HER2, Ki-67 immünhistokimyasal boyamalarının çalışılması için güvenilir materyaller olduğu sonucuna varılmıştır. Ayrıca Ki67, HER2 negatif tümörlerin moleküler subtiplemesinde önemli olduğu görülmüştür.

Anahtar kelimeler: Meme, iğne biyopsi, hormon reseptör, moleküler sınıflama.

Arman Karakaya Y, Yılmaz S, Karabaş H. Meme kanseri trucut iğne biyopsi ve rezeksiyon materyallerinde yeni moleküler sınıflama, tanı ve hormon reseptörlerinin durumu tutarlı mı? Pam Tıp Derg 2021;14:416-427.

\begin{abstract}
Purpose: The aim of this study was to evaluate the the concordance rate of molecular subtypes histological grade, estrogen receptor $(E R)$, progesterone receptor $(\mathrm{PgR})$ and human epidermal growth factor receptor 2 (HER2) levels between the diagnostic biopsy and resection materials in breast cancer, in the light of the literature. Materials and methods: Trucut needle biopsy (TNB) and resection materials of 64 cases, diagnosed at Department of Pamukkale University Medical Faculty Pathology, between 2018 May and 2020 November were included in this study. Tumor type, degree and pathological information on ER, PgR, HER2, Ki-67, immunohistochemically and HER2 status by molecular FISH method were analyzed retrospectively.

Results: : Concordance rate between resection specimens and trucut needle biopsy is $93.75 \%$. The concordance rates for ER, PgR, HER are 89\% (kappa, 0.685, $p<0.001$ ), 81.8\% (kappa, 0.645, $p<0.001$ ), 95\% (kappa=8.68, $p<0.001)$, respectively. HER2 concordance rates is better than ER and PgR receptor concordance rates. In Ki-67, a moderate agreement (kappa, $0.447, p<0.001$ ) was observed at a rate of $79 \%$. A good agreement $79 \%$ (kappa, $0.637, p<0.001$ ) was found in the grade comparison. Concordance rate between molecular classification was $93 \%$ and very good agreement (kappa, $0.882, p<0.001$ ) was found. Luminal $A$ is the most common type and the concordance rate is $97 \%$.

Conclusion: A high agreement was observed between diagnostic biopsy and resection materials. It was concluded that TIBs are reliable materials for determining the histopathological characteristics of the tumor, and
\end{abstract}

Yeliz Arman Karakaya, Dr. Öğr. Üye. Pamukkale Üniversitesi Tıp Fakültesi, Tıbbi Patoloji Anabilim Dalı, Denizli, Türkiye, e-posta: yelizkarakaya20@gmail.com (https://orcid.org/0000-0002-6669-9972) (Sorumlu Yazar)

Sevda Yılmaz, Dr. Öğr. Üye. Pamukkale Üniversitesi Tıp Fakültesi Genel Cerrahi Anabilim Dalı, Denizli, Türkiye, e-posta: syilmaz_md@hotmail.com (https://orcid.org/0000-0002-1309-0805)

Hande Karabaş, Arş. Gör. Dr. Pamukkale Üniversitesi Tıp Fakültesi Tıbbi Patoloji Anabilim Dalı, Denizli, Türkiye, e-posta: handekarabas95@gmail.com (https://orcid.org/0000-0003-3064-3499) 
studying the immunohistochemical staining of ER, PgR, HER2, Ki-67, which are important in diagnosis, treatment and prognosis. In addition, Ki-67 has been found to be important in molecular subtyping of HER2 negative tumors.

Key words: Breast, needle biopsy, hormone receptor, molecular classification.

Arman Karakaya Y, Yilmaz S, Karabas H. Are the new molecular classification, diagnosis and status of hormone receptors compatible between core needle biopsy and surgical specimen in breast cancer? Pam Med J 2021;14:416-427.

\section{Giriş}

Meme kanseri kadınlarda en sık görülen malignitedir ve gelişmekte olan ülkelerde kadınların kansere bağlı ölümlerin önde gelen nedenidir [1]. Meme kanserinden, dünyada 2018 'de 2.088.849 (\%11,6) yeni vaka ve $626.679(\% 6,6)$ ölüm meydana gelmiştir [2]. Türkiye'de 2018 'de bildirilen 22.345 yeni olgu sayısı ile kadınlardaki kanser vakalarının \%24'ünü ve açık ara en fazla ortaya çıkan kanser türünü oluşturmaktadır. Meme kanseri vakalarının dünya genelinde 2050 yılına kadar yıllık 3,2 milyona ulaşacağı tahmin edilmektedir [3]. Önemli bir kanser nedeni olmaya devam etmesine rağmen morbidite ve mortalite büyük ölçüde erken teşhis ve daha etkili tedavi nedeniyle azalmıştır [4].

2015 Avrupa Tıbbi Onkoloji Derneği (ESMO) kılavuzu hormon reseptör (HR) ve human epidermal growth factor receptor 2 (HER2) durumunun ilk olarak trucut iğne biyopsisi (TiB) ile test edilmesini önerir; bu, daha ileri sistemik tedaviye rehberlik etmek için kullanılabilir [5]. TíB hem palpe edilebilen, hem de palpe edilemeyen meme lezyonları için önemli bir tanı aracı olmuş ve doku örneklemesi için tercih edilen bir yöntem olarak kabul edilmiştir [6, 7]. Ayrıca TiB, eksizyon biyopsisine göre daha az invazivdir ve özellikle patolojik bilgi sağlamak için ince iğne aspirasyon biyopsi sitolojisine (IiAS) kıyasla genellikle daha güvenilirdir. Bir meme lezyonunun doğru preoperatif tanısı, gecikmeden ve minimum biyopsi ile kesin bir tanıya ulaşmak için optimal bir tedavi algoritması tasarlamak için gerekli kabul edilmiştir [8]. Meme kanseri teşhisinde ilk prosedür olarak TíB, HR, HER2 ve Ki-67 durumu gibi tümör biyobelirteçlerini test etmek için yaygın olarak kullanılır ve önerilir. TíB'nin meme kanseri tanısı için doğruluğu \%95'ten fazladır [1].

Meme kanseri, dört moleküler alt tipte sınıflandırılan heterojen bir hastalıktır: Luminal
A, luminal B, HER2 aşırı ekspresse pozitif ve üçlü negatif. Östrojen reseptörü (ER), progesteron reseptörü $(\mathrm{PgR}), \mathrm{HER} 2$ ve $\mathrm{Ki}$ 67 için immünohistokimya, moleküler alt tip sınıflandırmalarını tanımlamak için kullanıır [9]. Meme kanseri alt tipini tespit etmek, hastalığın prognozu yanı sıra tedaviyi belirlemek için de önemlidir. Bu nedenle, rutin histopatolojik analiz için meme kanseri alt tipinin belirlenmesi gereklidir [10]. HER2 aşırı ekspresse ve üçlü negatif alt tipleri kötü prognoza sahipken, luminal $A$ ve $B$ alt tipleri daha iyi prognoza sahiptir [11].

Meme kanseri tanısı almış olgularda, TiB ve rezeksiyon materyalleri arasında histopatolojik özelliklerin tanısal uyumunun ve histolojik derece, tümör moleküler alt tipleri, $E R, P R$ ve HER2 düzeylerinin karşılaştırılarak sonuçların literatür eşliğinde değerlendirilmesi amaçlanmıştır.

\section{Gereç ve yöntem}

\section{Olgular}

2018 Mayıs-2020 Kasım tarihleri arasında YAK tarafından raporlanmış 64 adet TíB ve aynı hastalara ait rezeksiyon materyalleri çalışmaya alınmıştır. Hastalara ait yaş, cinsiyet gibi klinik bilgiler, TiB ve rezeksiyon materyallerinde tümör tipi, tümör çapı, odak sayısı, grade, lenfovasküler invazyon, meme başı invazyonu, aksiller metastaz, tedavi durumu ve immunohistokimyasal olarak ER, PgR, HER2, Ki-67, moleküler FISH yöntemi ile HER2 durumuna ait patolojik bilgiler retrospektif olarak hastane sisteminden taranarak bulunmuştur.

$\mathrm{Bu}$ çalışmanın etik kurulu, Pamukkale Üniversitesi Girişimsel Olmayan Klinik Araştırmalar Etik Kurulu tarafından 19.10.2020 tarih ve 63657 sayılı toplantıda kabul edilmiştir.

\section{Histopatolojik değerlendirme}

Histopatolojik değerlendirmeler Dünya Sağlık Örgütü (DSÖ) meme tümörlerinin [12] 
histolojik sınıflandırmasına ve Rosen'in Meme Patolojisine dayanmaktadır [13]. Tüm meme tümörlerinin biyopsi ve rezeksiyon örneğinde histolojik/nükleer derece ve mitoz oranı, Modifiye Bloom Richardson derecelendirme sistemine göre belirlendi. Histolojik derece; skor 1 (>\%75 tümör alanındaki glandular/tubular yapılar), skor 2 (\%10-\%75 tümör alanındaki glandular/tubular yapılar), Skor 3 (<\%10 tümör alanındaki glandular/tubular yapılar), nükleer atipi; (düşük dereceli atipi için 1; orta derece atipi için 2; yüksek dereceli atipi için 3), mitoz oranı; 10 büyük büyütme alanı başına mitotik sayım puanları (40 objektif lens, Nickon Eclips E200 mikroskobunda) (0-7 mitoz için 1; 7-14 mitoz için 2; >15 mitoz için 3) olarak skorlandı. Histolojik derece, nükleer atipi ve mitotik sayım skorlarının toplamı sırasıyla 3-4-5 olduğunda 1 ve 6-7 olduğunda 2, 8-9-10 olduğunda 3 olarak skorlanmıştır [12, 13].

\section{ER, PgR, HR, HER2, Ki-67 yöntem ve değerlendirmesi}

Tüm TíB ve rezeksiyon materyallerinde, Pamukkale Üniversite Hastanesi Patoloji Bölümü'nde hematoksilen-eozin (H\&E) ve ER, $\mathrm{PgR}, \mathrm{HER} 2$ ile Ki-67 için immünohistokimyasal boyama yapıldı. Tüm TíB ve rezeksiyon materyallerinden sonra, örnekler \%10 formalin içinde sabitlendi, parafine gömüldü, 4 mikron kalınlığında kesitler alındı ve lamlar üzerine yerleştirildi. Kesilen 4 mikronluk kesitler üzerinde immünohistokimya uygulandı. Doku deparafinizasyonundan sonra, ER (SP1 Rabbit monoclonal, Ventana, USA), PgR (1E2, Rabbit monoclonal ventana, USA), HER2 (SP3 Rabbit monuclonal, Cell, Marque, USA), Ki-67 (30-9, Rabbit monoklonal Ventana, ABD) antikoru uygulandı. iView DAP Detection kit (Ventana Medical System) daha sonra sekonder antikor olarak kullanıldı. Pozitif ve negatif kontroller uygulandı. \%1'in üzerindeki nükleer immünekspresyon, ER ve $\mathrm{PgR}$ durumu için pozitif kabul edildi. ER ve PgR pozitif tümör hücrelerinin sayısını aşağıdaki kriterlere göre de değerlendirdik:0; 0-<\%1, 1; \%1-10 ve $2 ;>\% 10$ [8]. ER ve PgR'den ikisinin ya da birinin pozitifliği (>\%1) HR pozitif, ER ve PgR negatifliği (<\%1) HR negatif olarak kabul edildi. HER2 pozitifliği, American Society of Clinical Oncology/College of American Pathologists (ASCO-CAP) skorlama sistemi [14] ile sadece membranöz boyama değerlendirildi. HER2 protein ekspresyonunun yoğunluğu, boyama yüzdesi yarı kantitatif olarak değerlendirildi ve 0 ile $3+$ arasında derecelendirildi. 0 ve $1+$ skorları negatif, \%10'dan fazlası 2+ ve 3+ pozitif olarak kategorize edildi. 2+ olan grupta HER2 ekspresyon durumunu doğrulamak için Leica HER2 FISH testi yapıldı. Ki-67 için invaziv tümör hücrelerinde manuel olarak hotspot alandaki boyanma yüzdesi verildi. Ki-67 için cutoff değeri \%20 olarak alındı.

\section{Moleküler alt tip sınıflaması}

Meme kanseri heterojen bir hastalıktır; bu nedenle, moleküler alt tipler genetik testlere ve/ veya immünohistokimyasal analizlere dayalı olarak oluşturulmuştur. Moleküler alt tipler, ER/PgR/HER2 onkojen ekspresyonunun ve Ki-67 indeksinin varlığına dayanmaktadır. En son 2013 yılında St. Gallen konsensüsü ile güncellenen beş alt tip belirlenmiştir:

-Luminal A (ER pozitif, PgR $>\% 20$, HER2 negatif ve $\mathrm{Ki}-67$ indeks $<\% 20$ ),

-Luminal B/HER2 negatif (ER pozitif, PgR $<\% 20$, HER2 negatif ve Ki-67 indeksi>\%20),

-Luminal B/HER2 pozitif (ER pozitif, herhangi bir PgR, HER2 pozitif ve herhangi bir Ki-67 indeksi),

•HER2 aşırı eksprese (ER negatif, PgR negatif, HER2 pozitif ve herhangi bir Ki-67 indeksi)

- Üçlü negatif (bazal benzeri) (ER negatif, PgR negatif, HER2 negatif ve herhangi bir Ki-67 indeksi) [15].

\section{İstatiksel analiz}

Rezeksiyon materyalleri ile TíB arasında, moleküler alt tipler ve hormon reseptörleri yüzde ve kappa (K) değeri hesaplandı. K değerleri $<0,20$, çok az uyum ile korele, 0,21-0,40 az uyum, 0,41-0,60 orta düzeyde uyum, 0.610,80 iyi uyum ve $0,81-1,00$ çok iyi uyum olarak değerlendirildi [8]. P-değerleri, Ki-kare testi veya Fisher exact test kullanılarak hesaplandı ve $p<0,05$ değeri anlamlı kabul edildi. İstatistiksel analizler IBM SPSS 20 Statistics kullanılarak yapıldı.

\section{Bulgular}

Olguların 63 (\%98,4)'ü kadın, 1 (\%1,6)'sı erkektir. Yaş ortalaması 55 513,07 'dir. 23 $(\% 35,9)$ 'u sağ meme, $41(\% 64,1)$ 'i sol meme 
yerleşimlidir. TíB sonrası 64 olgunun 10 (\%15,6)'una eksizyonel biyopsi, 54 $(\% 84,4)$ 'üne modifiye radikal mastektomi cerrahisi uygulanmıştır. $55(\% 85,9)$ 'i bir odakta görülürken, $8(\% 12,5)$ 'i 2 odakta, 1 (\%1,6)'i 7 odakta görüldü. $13(\% 20,3)$ 'ünde aksiller lenf nodu metastazı görülürken, $52(\% 79,7)$ 'sinde görülmedi. $5(\% 7,8)$ 'inde T7, T12 vertebra, vokal kord, kosta, tiroid ve mideye uzak metastaz vardır. $6(\% 9,4)$ olguda meme başı invazyonu görülürken, $58 \quad(\% 90,6)$ olguda görülmedi. $9(\% 14,1)$ olguda lenfovasküler invazyon olmasına rağmen, $55(\% 85,9)$ olguda yoktur. $14(\% 21,9)$ 'u neoadjuvan tedavi almış olup, $50(\% 78,1)$ 'i almamıştır. 26 (\%40,6)'sına sadece cerrahi tedavi, 25 (\%39,1)'ine cerrahi ve kemoterapi, 13 (\%20,3)'üne cerrahi, kemoterapi ve radyoterapi uygulanmıştır. Hasta tümör özellikleri ve patolojik sonuçlar Tablo 1'de gösterilmiştir.

Tablo 1. Olguların klinikopatolojik özellikleri

\begin{tabular}{|c|c|c|}
\hline \multicolumn{2}{|l|}{ Tümör ve hasta özellikleri } & \multirow[t]{2}{*}{ Sayı (\%) } \\
\hline Yaş (Median) & $55(34-93)$ & \\
\hline & $\leq 50$ & $25(39,1)$ \\
\hline & $>50$ & $39(60,9)$ \\
\hline \multirow[t]{3}{*}{ Tümör boyutu (Median) } & $2 \mathrm{~cm}(0,1-17)$ & \\
\hline & $\leq 2 \mathrm{~cm}$ & $28(43,8)$ \\
\hline & $>2 \mathrm{~cm}$ & $36(56,2)$ \\
\hline \multicolumn{3}{|l|}{$\underline{\text { Cerrahi tipi }}$} \\
\hline \multicolumn{2}{|l|}{ Meme koruyucu cerrahi } & $10(15,6)$ \\
\hline \multicolumn{2}{|l|}{ Mastektomi } & $54(84,4)$ \\
\hline \multicolumn{3}{|c|}{ Patolojik tip (rezeksiyon) } \\
\hline \multicolumn{2}{|c|}{ Invasiv karsinoma, spesifik olmayan tip (invaziv duktal karsinoma) } & $51(79,7)$ \\
\hline \multicolumn{2}{|c|}{ Invasive lobular carcinoma } & $4(6,2)$ \\
\hline \multicolumn{2}{|l|}{ İnvaziv tübüler karsinom } & $3(4,7)$ \\
\hline \multicolumn{2}{|l|}{ Mikst karsinom } & $4(6,2)$ \\
\hline \multicolumn{2}{|l|}{ Mikroinvaziv karsinom } & $1(1,6)$ \\
\hline \multicolumn{2}{|c|}{ İnvaziv mikropapiller karsinom } & $1(1,6)$ \\
\hline \multicolumn{3}{|c|}{ Histolojik grade (Nottingham histolojik grade) (rezeksiyon) } \\
\hline \multicolumn{2}{|c|}{ Grade 1} & $11(17,5)$ \\
\hline \multicolumn{2}{|l|}{ Grade 2} & $29(46)$ \\
\hline \multicolumn{2}{|l|}{ Grade 3} & $23(36,5)$ \\
\hline \multicolumn{3}{|l|}{ Patolojik T kategorisi (rezeksiyon) } \\
\hline \multicolumn{2}{|l|}{ pT1 } & $35(54,7)$ \\
\hline \multicolumn{2}{|l|}{ pT2 } & $22(34,4)$ \\
\hline \multicolumn{2}{|l|}{ pT3 } & $3(4,7)$ \\
\hline \multicolumn{2}{|l|}{ pT4 } & $4(6,3)$ \\
\hline \multicolumn{3}{|l|}{ Patolojik N kategorisi(rezeksiyon) } \\
\hline \multicolumn{2}{|l|}{ pNO } & $52(81,3)$ \\
\hline \multicolumn{2}{|l|}{$\mathrm{pN} 1$} & $8(12,5)$ \\
\hline \multicolumn{2}{|l|}{ pN2 } & $2(3,1)$ \\
\hline \multicolumn{2}{|l|}{ pN3 } & $2(3,1)$ \\
\hline
\end{tabular}

\section{Rezeksiyon materyali ile trucut biyopsiler arasındaki tanı uyumu}

TíB'de tip belirtilmeyen, invaziv karsinom tanısı konulan 14 olgunun 9'una rezeksiyon materyalinde invaziv karsinom, NOS (invaziv duktal karsinom), 1'ine lobüler karsinom, 1 'ine mikst karsinom, 1'ine medüller özellik gösteren invaziv karsinom tanısı konmuştur.
Tỉ'de invaziv karsinom, NOS (invaziv duktal karsinom) tanısı konulan 45 olgudan 41'ine rezeksiyon materyalinde invaziv karsinom, NOS (invaziv duktal karsinom), 3'üne mikst karsinom, 1'ine invaziv mikropapiller karsinom tanısı konmuştur. İnvaziv lobüler karsinom tanısı konulan 3 olguya, rezeksiyon materyalinde de invaziv lobüler karsinom tanısı ile tam uyum 
görülmüştür. TỉB'de invaziv tübüler karsinom tanısı konulan 1 olguya rezeksiyonda da invaziv tübüler karsinom tanısı ile tam uyum görülmüştür. TİB tanı verilebilen lezyonlar ile rezeksiyon materyallerin histolojik tipi arasındaki uyuma baktığımızda, uyum oranı \%93,75’tir. Ayrıca trucut biyopside duktal karsinoma insitu tanısı konulan bir olgu rezeksiyon materyalinde mikroinvaziv karsinom tanısı almış, ancak bu olguya invazyon alanı kısıtlı olduğu için grade verilememiştir.

\section{Rezeksiyon materyali ile trucut biyopsiler arasındaki ER, PgR, HR, HER2 ve Ki67 uyumu}

Rezeksiyon materyalinde ER reseptörü 14 (\%21,9)'ünde <\%1, 50 (\%78,1)'sinde $\geq \% 10$ 'dur. Biyopsi ve rezeksiyon materyallerinde ER boyanma yüzdesi bakımından bire bir uyum olan 57 olgu belirlendi. Uyum oranı \%89'dur. Trucut biyopside ER 4 olguda \%1-10 arasında bulunurken, rezeksiyon materyalinde 2'si <\%1, 2'si $\geq \% 10$ tespit edilmiştir. TỉB'de $\geq \% 103$ olgu, rezeksiyonda $<\% 1$ bulunmuştur (Tablo 2). Meme rezeksiyon ile TíB arasındaki ER için iyi uyum (kappa, 0,685, $p<0,001$ ) bulunmuştur.

Rezeksiyon materyalinde $\mathrm{PgR}$ reseptörü 15 (\%23,4)'inde <\%1, 9 (\%14,1)'unda \%1-10 arasında ve $40(\% 62,5)$ 'ında $\geq \% 10$ 'dur. Biyopsi ve rezeksiyon materyallerinde $\mathrm{PgR}$ boyanma yüzdesi bakımından bire bir uyum olan 52 olgu belirlendi. Uyum oranı \%81'dir. TíB'de PgR, 6 olguda $<\% 1$ iken, rezeksiyon materyalinde \%110 arasında, 2'sinde $\geq \% 10$ 'dur. TíB'de PgR, 2 olguda \%1-10 arasında iken, rezeksiyon materyalinde <\%1'dir. TỉB'de 2 olguda $\geq \% 10$ iken, rezeksiyon materyalinde <\%1 tespit edilmiştir (Tablo 3). PgR için, iyi uyum (kappa, $0,645, p<0,001)$ vardır.
Biyopsi ve rezeksiyon materyallerinde HR boyanma yüzdesi bakımından bire bir uyum olan 59 olgu belirlendi. Uyum oranı \%92'dir. Trucut biyopside ve rezeksiyon materyalinde HR negatifliğinde tam uyum görülmüştür, Trucut biyopside 5 olguda HR pozitif iken, bu olgular rezeksiyon materyalinde negatif bulunmuştur. Rezeksiyon materyalinin 14 (\%21,9)'ünde HR'leri negatif, 50 (\%78,1)'inde HR'leri pozitiftir (Tablo 4). HR uyumu karşılaştırıldığında uyum oranı iyidir (kappa, 0,734, $p<0,001$ ).

Meme rezeksiyon materyallerinde 50 $(\% 78,1)$ 'si skor 0-1, 2 (\%3,1)'si skor 2, 12 $(\% 18,8)$ 'si skor 3'tür (Tablo 5). Skor 2 olan 2 rezeksiyon materyeline FiSH yöntemi ile HER2 uygulanmış olup, amplifikasyon görülmüştür. TỉB materyallerinden 3'ünde skor 2 izlenmiş olup, FISH yöntemi ile HER2 uygulanmış ve 2'sinde amplifikasyon görülmüş, 1'inde görülmemiştir. Amplifikasyon görülen 2 olgunun 1 'inde rezeksiyon materyali immünohistokimyasal olarak HER2 negatif, diğerinde skor 2'dir. Amplifikasyon görülmeyen trucut biyopsinin rezeksiyon materyalinde, HER2 immünekspresyonu skor 0'dir. Meme rezeksiyon ile Tỉ'ler arasındaki HER2 için uyum oranı \%95'dir. Uyum çok iyi olup, kappa, 0,868, $p<0,001$ 'dir. HER2 uyum oranı HR, ER ve $\mathrm{PgR}$ reseptör uyum oranına göre daha iyidir.

Biyopsi ve rezeksiyon materyallerinde $\mathrm{Ki}$ 67 boyanma yüzdesi bakımından bire bir uyum olan 51 olgu belirlendi. Uyum oranı \%79'dur. TíB'de 6 olgu <\%20 bulunurken, rezeksiyon materyalinde bu olgular $\geq \% 20$ 'dir. TíB'de 7 olgu $\geq \% 20$ iken, rezeksiyon materyalinde bu olgular <\%20'dir. Rezeksiyon materyallerinde 48 (\%75)'inde Ki-67 $\geq \% 20,16$ (\%25)'inde Ki$67<\% 20$ 'dir (Tablo 6). Meme rezeksiyon ile TỉB'ler arasındaki Ki-67 oranına baktığımızda

Tablo 2. Rezeksiyon materyali ile trucut biyopsiler arasındaki ER durumu

\begin{tabular}{|c|c|c|c|c|c|}
\hline & & & \multicolumn{3}{|c|}{ Rezeksiyon materyali ER durumu } \\
\hline & & & $<\% 1$ & $\geq \% 10$ & Toplam \\
\hline & $<\% 1$ & Sayı & 9 & 0 & 9 \\
\hline \multirow{4}{*}{ Trucut materyali ER durumu } & & $\%$ & $\% 100,0$ & $\% 0,0$ & $\% 100,0$ \\
\hline & $\% 1-10$ & Sayı & 2 & 2 & 4 \\
\hline & & $\%$ & $\% 50,0$ & $\% 50,0$ & $\% 100,0$ \\
\hline & $\geq \% 10$ & Sayı & 3 & 48 & 51 \\
\hline \multirow{3}{*}{ Toplam } & & $\%$ & $\% 5,9$ & $\% 94,1$ & $\% 100,0$ \\
\hline & & Sayı & 14 & 50 & 64 \\
\hline & & $\%$ & $\% 21,9$ & $\% 78,1$ & $\% 100,0$ \\
\hline
\end{tabular}


Tablo 3. Rezeksiyon materyali ile trucut biyopsiler arasındaki PR durumu

\begin{tabular}{|c|c|c|c|c|c|c|}
\hline & & \multicolumn{5}{|c|}{ Rezeksiyon materyali PR durumu } \\
\hline & & & $<\% 1$ & $\% 1-10$ & $\geq \% 10$ & Toplam \\
\hline & $<\% 1$ & Sayı & 11 & 6 & 2 & 19 \\
\hline & & $\%$ & $\% 57,9$ & $\% 31,6$ & $\% 10,5$ & $\% 100,0$ \\
\hline \multirow{4}{*}{$\begin{array}{l}\text { Trucut materyali PR } \\
\text { durumu }\end{array}$} & $\% 1-10$ & Sayı & 2 & 3 & 0 & 5 \\
\hline & & $\%$ & $\% 40,0$ & $\% 60,0$ & $\% 0,0$ & $\% 100,0$ \\
\hline & $\geq \% 10$ & Sayı & 2 & 0 & 38 & 40 \\
\hline & & $\%$ & $\% 5,0$ & $\% 0,0$ & $\% 95,0$ & $\% 100,0$ \\
\hline \multirow[t]{2}{*}{ Toplam } & & Sayı & 15 & 9 & 40 & 64 \\
\hline & & $\%$ & $\% 23,4$ & $\% 14,1$ & $\% 62,5$ & $\% 100,0$ \\
\hline
\end{tabular}

Tablo 4. Rezeksiyon materyali ile trucut biyopsiler arasındaki hormon reseptör durumu karşılaştırması

\begin{tabular}{|c|c|c|c|c|c|}
\hline & & & \multicolumn{2}{|c|}{$\begin{array}{l}\text { Rezeksiyon materyali hormon } \\
\text { reseptör durumu }\end{array}$} & \multirow[b]{2}{*}{ Toplam } \\
\hline & & & Negatif & Pozitif & \\
\hline \multirow{4}{*}{$\begin{array}{l}\text { Trucut materyali hormon } \\
\text { reseptör durumu }\end{array}$} & Negatif & Sayı & 9 & 0 & 9 \\
\hline & & $\%$ & $\% 100,0$ & $\% 0,0$ & $\% 100,0$ \\
\hline & Pozitif & Sayı & 5 & 50 & 55 \\
\hline & & $\%$ & $\% 9,1$ & $\% 90,9$ & $\% 100,0$ \\
\hline \multirow[t]{2}{*}{ Toplam } & & Sayı & 14 & 50 & 64 \\
\hline & & $\%$ & $\% 21,9$ & $\% 78,1$ & $\% 100,0$ \\
\hline
\end{tabular}

Tablo 5. Rezeksiyon materyali ile trucut biyopsiler arasındaki HER2 skoru karşılaştırması

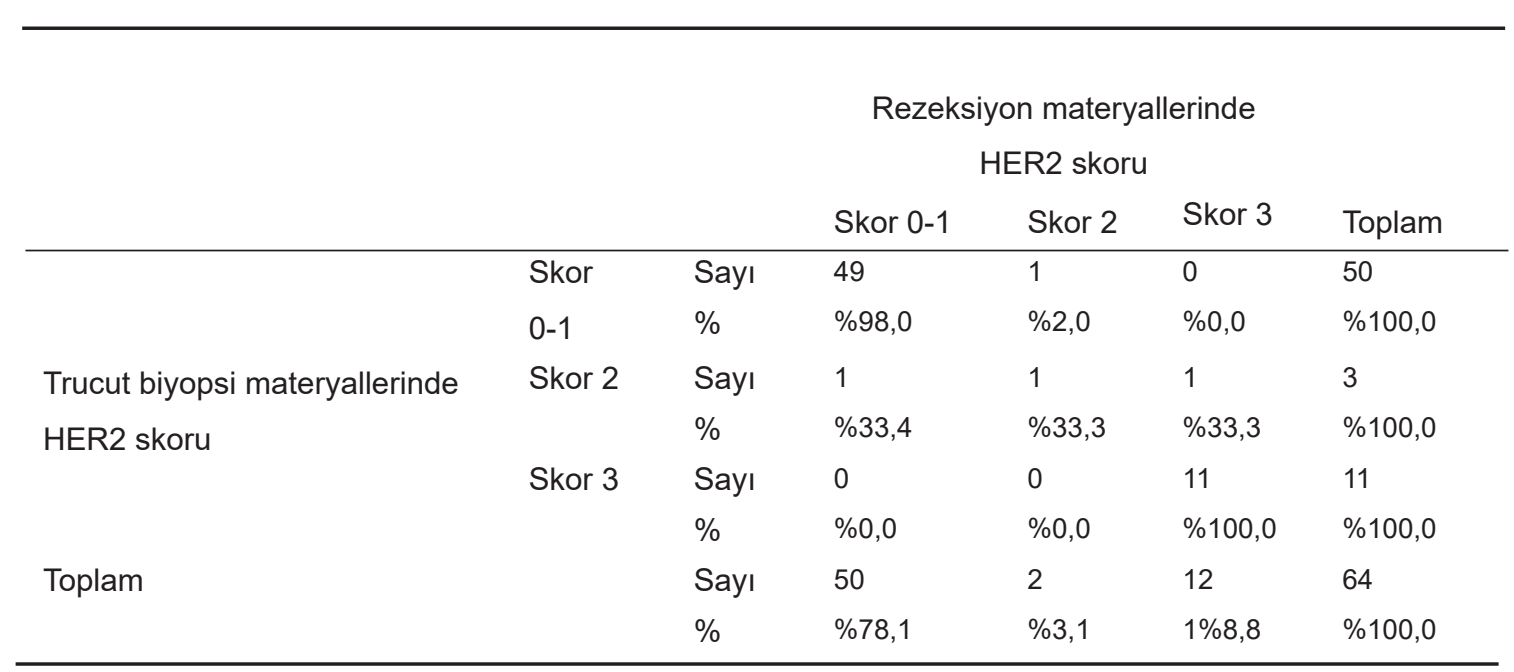


Tablo 6. Rezeksiyon materyali ile trucut biyopsiler arasındaki Ki-67 oranı karşılaştırması

\begin{tabular}{|c|c|c|c|c|c|}
\hline & & \multicolumn{4}{|c|}{ Rezeksiyon materyali Ki-67 } \\
\hline & & & $<\% 20$ & $\geq \% 20$ & Toplam \\
\hline \multirow[t]{4}{*}{ Trucut biyopsi Ki-67 } & $<\% 20$ & Sayı & 9 & 6 & 15 \\
\hline & & $\%$ & $\% 60,0$ & $\% 40,0$ & $\% 100,0$ \\
\hline & $\geq \% 20$ & Sayı & 7 & 42 & 49 \\
\hline & & $\%$ & $\% 14,3$ & $\% 85,7$ & $\% 100,0$ \\
\hline \multirow[t]{2}{*}{ Toplam } & & Sayı & 16 & 48 & 64 \\
\hline & & $\%$ & $\% 25,0$ & $\% 75,0$ & $\% 100,0$ \\
\hline
\end{tabular}

orta düzeyde uyum (kappa, 0,447, p<0,001) görülmüştür.

\section{Rezeksiyon materyali ile trucut biyopsiler arasındaki tümör derece karşılaştırması}

Rezeksiyon materyallerinde 10 (\%15,9)'u derece 1, 40 (\%63,5)'ı derece 2, 13 (\%20 ,6)'ü derece 3 'tür. Trucut biyopside derece 1 grubundaki 9 olgu, rezeksiyon materyalinde derece 2 grupta bulunmuştur. Trucut biyopside derece 2 gruptaki 4 olgudan 2'si rezeksiyon materyalinde derece 1 grupta, 2'si derece 2 gruptadır. Derece 3 grupta 13 olgu olup biyopsi ve rezeksiyon materyalinde tam uyum vardır (Tablo 7). Meme rezeksiyon ile TỉB'ler arasındaki derece karşılaştırmasında uyum oranı \%79 olup, iyi uyum (kappa, 0,637, $p<0,001$ ) bulunmuştur.

Tablo 7. Rezeksiyon materyali ile trucut biyopsiler arasında derece karşılaştırması

\begin{tabular}{|c|c|c|c|c|c|c|}
\hline & & & \multicolumn{3}{|c|}{ Rezeksiyon materyali derece } & \multirow[b]{2}{*}{ Toplam } \\
\hline & & & derece 1 & derece 2 & derece 3 & \\
\hline \multirow{6}{*}{$\begin{array}{l}\text { Trucut biyopsi } \\
\text { derece }\end{array}$} & derece 1 & Sayı & 8 & 9 & 0 & 17 \\
\hline & & $\%$ & $\% 47,1$ & $\% 52,9$ & $\% 0,0$ & $\% 100,0$ \\
\hline & derece 2 & Sayı & 2 & 31 & 2 & 35 \\
\hline & & $\%$ & $\% 5,7$ & $\% 88,6$ & $\% 5,7$ & $\% 100,0$ \\
\hline & derece 3 & Sayı & 0 & 0 & 11 & 11 \\
\hline & & $\%$ & $\% 0,0$ & $\% 0,0$ & $\% 100,0$ & $\% 100,0$ \\
\hline \multirow[t]{2}{*}{ Toplam } & & Sayı & 10 & 40 & 13 & 63 \\
\hline & & $\%$ & $\% 15,9$ & $\% 63,5$ & $\% 20,6$ & $\% 100,0$ \\
\hline
\end{tabular}

\section{Rezeksiyon materyali ile trucut biyopsiler arasındaki moleküler subtiplerin uyumu}

Rezeksiyon materyallerinde 42 (\%65,6)'si lüminal $A, 10(\% 15,6)$ 'u lüminal $B, 4(\% 6,3)$ 'ü HER2 aşırı eksprese, 8 (\%12,5)'i üçlü negatiftir. Trucut biyopside lüminal $\mathrm{A}$ grubundaki 1 olgu, rezeksiyon materyalinde triple negatif grupta bulunmuştur. Trucut biyopside lüminal B gruptaki 3 olgudan 2'si rezeksiyon materyalinde lüminal A grupta, 1'i HER2 aşırı eksprese gruptadır. HER2 aşırı eksprese grupta 3 olgu, üçlü negatif grupta 7 olgu mevcut olup, tam uyum vardır (Tablo 8). Meme rezeksiyon ile trucut biyopsiler arasındaki moleküler sınıflama arasında uyum oranı \%93 olup, çok iyi uyum (kappa, 0,882, p<0,001) bulunmuştur. Lüminal $A$ en fazla görülen tip olup, uyum oranı \%97'tür. Uyum oranı lüminal B'de $\% 76$, HER2 aşırı eksprese grupta $\% 100$, üçlü negatif grupta \%100'dür. Luminal B, luminal B/ HER2 negatif ve luminal B/HER2 pozitif olarak alt gruplara ayrıldığında, uyum oranı \%76,9 olup, rezeksiyon materyalinde 8 olgu lüminal B/HER2 pozitif, 2 olgu lüminal B/HER2 negatif gruptadır. TỉB ile rezeksiyon materyali arasında 3 olgudaki uyumsuzluğun nedeni, 2 olguda Ki67 oranındaki farklılık, 1 olguda HR'lerin farklı olmasından kaynaklanmaktadır. 
Tablo 8. Rezeksiyon materyali ile trucut biyopsiler arasında moleküler sınıflama karşılaştırması

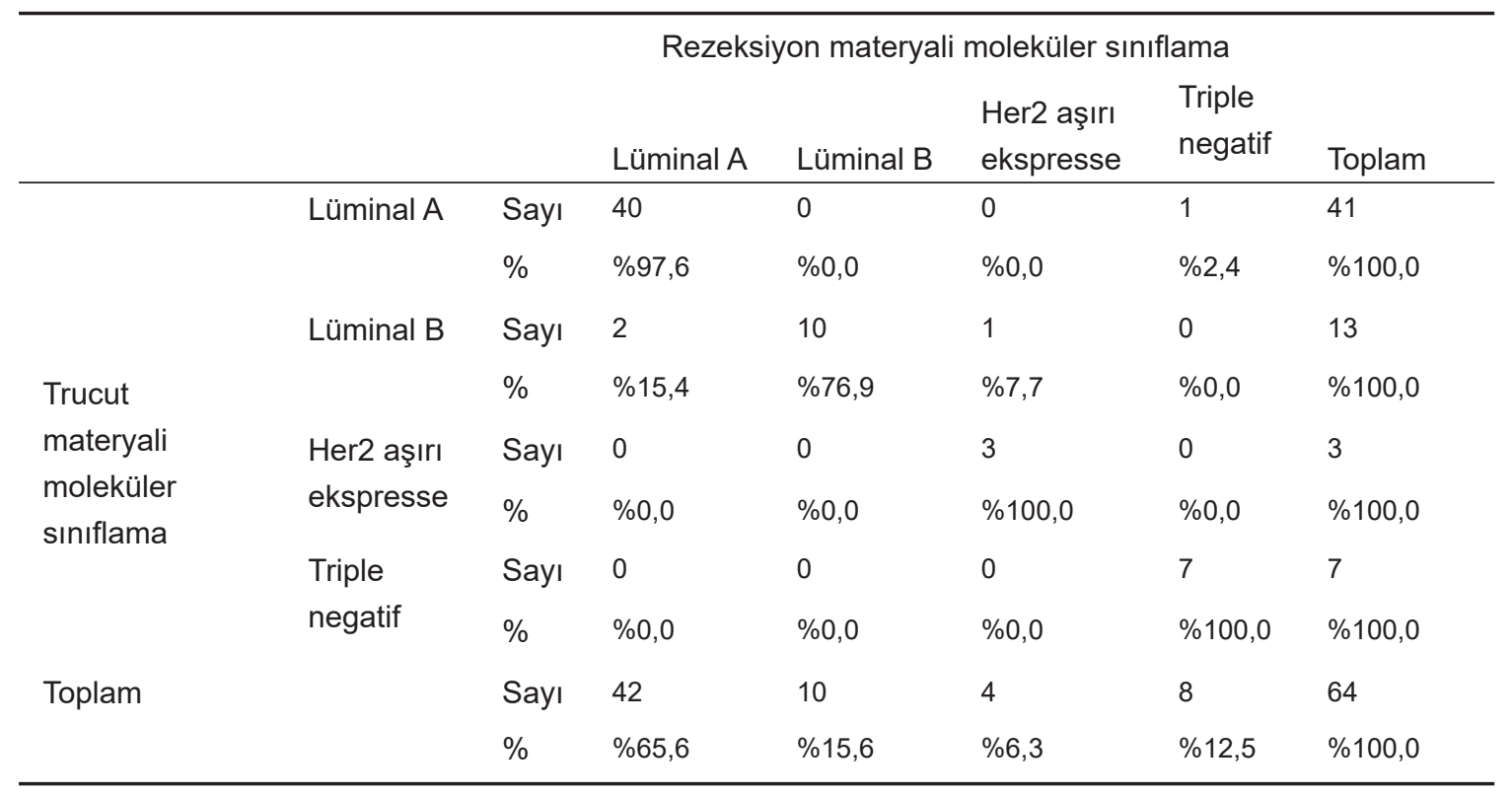

\section{Rezeksiyon materyalinde moleküler sınıflama ile tümör derece karşılaştırması}

Rezeksiyon materyallerinde tümör derecesi ile moleküler sınıflama karşılaştırıldığında lüminal A (30 olgu, $\% 73,2)$ ve lüminal $B(7$ olgu, $\% 58,3$ ) gruplarında 37 olguda derece 2 , HER2 aşırı ekspresse (2 olgu, \%66,7) ve üçlü negatif (5 olgu, \%71,4) gruplarda 7 olguda derece 3 mevcuttur. HER2 aşırı eksprese ve üçlü negatif gruplarda derece 3 oranı, lüminal $A$ ve lüminal B'ye göre daha fazla bulunmuştur $(p=0,003)$ (Tablo 9).

Ayrıca TiB ve rezeksiyon materyali ER, PgR, HR, HER2, Ki-67, derece, yeni moleküler sınıflama ile tümör boyutu, odak sayısı, lokalizasyon, meme başı invazyonu, lenfovasküler invazyon, aksiller lenf nodu metastazı, uzak metastaz arasındaki ilişki karşılaştırılmıştır. Rezeksiyon materyalinde HER2 skor 2 olan $2(\% 100)$ olguda tümör çapı $\geq 5 \mathrm{~cm}$ iken, skor $0-1$ olan 45 (\%90) olguda $<5$ cm'dir. Skoru düşük olan olguların tümör çapı daha düşüktür $(p<0,001)$. HER2 skor 2 grupta (2 olgu, \%100) lenfovasküler invazyon, skor 0-1 gruba (7 olgu, \%14) göre daha fazla görülmüştür $(p=0,001)$.

Tỉ materyallerinde, meme başı invazyonu lüminal $B$ ve üçlü negatif grupta görülmemiş olup, lüminal A'da $4(\% 9,8)$ olguda, HER2 aşırı eksprese grupta $2(\% 66,7)$ olguda görülmüştür. Meme başı invazyonu HER2 aşırı eksprese grupta, lüminal A'ya göre daha fazla orandadır $(p=0,003)$. Rezeksiyon materyali moleküler sınıflamasına göre meme başı invazyonu, HER2 aşırı eksprese grupta (2 olgu, \%50), diğer gruplara göre daha fazla görülmüştür $(p=0,027)$.

ER, PgR, HR, Ki-67 ile tümör boyutu, odak sayısı, lokalizasyon, meme başı invazyonu, lenfovasküler invazyon, aksiller lenf nodu metastazı, uzak metastaz arasında anlamlı ilişki bulunamamıştır $(p<0,001)$. 
Tablo 9. Rezeksiyon materyali ile trucut biyopsiler arasında moleküler sınıflama ile tümör derece karşılaştırması

\begin{tabular}{|c|c|c|c|c|c|c|}
\hline & & \multicolumn{5}{|c|}{ Rezeksiyon materyali tümör derece } \\
\hline & & & derece 1 & derece 2 & derece 3 & Toplam \\
\hline \multirow[t]{8}{*}{ Tümör moleküler sınıflama } & Lüminal & Sayı & 8 & 30 & 3 & 41 \\
\hline & A & $\%$ & $\% 19,5$ & $\% 73,2$ & $\% 7,3$ & $\% 100,0$ \\
\hline & Lüminal & Sayı & 2 & 7 & 3 & 12 \\
\hline & B & $\%$ & $\% 16,7$ & $\% 58,3$ & $\% 25,0$ & $\% 100,0$ \\
\hline & Her 2 & Sayı & 0 & 1 & 2 & 3 \\
\hline & $\begin{array}{l}\text { aşırı } \\
\text { eksprese }\end{array}$ & $\%$ & $\% 0,0$ & $\% 33,3$ & $\% 66,7$ & $\% 100,0$ \\
\hline & Üçlü & Sayı & 0 & 2 & 5 & 7 \\
\hline & negatif & $\%$ & $\% 0,0$ & $\% 28,6$ & $\% 71,4$ & $\% 100,0$ \\
\hline \multirow[t]{2}{*}{ Toplam } & & Sayı & 10 & 40 & 13 & 63 \\
\hline & & $\%$ & $\% 15,9$ & $\% 63,5$ & $\% 20,6$ & $\% 100,0$ \\
\hline
\end{tabular}

\section{Tartışma}

Meme kanserinde neoadjuvan tedavi, tümör yükünü azaltarak meme koruyucu cerrahiyi kolaylaştırır ve aksillayı korumayı sağlayabilir. Ameliyat öncesi sistemik tedaviye yanıtı belirler [9]. Özellikle, neoadjuvan sistemik tedavi yöntemleri TíB'deki ER, PgR, HER2 ve Ki-67 durumuna göre belirlenen moleküler alt türe göre karar verilir. Bunlar ayrıca meme kanseri hastalarının prognozlarını tahmin etmek için kullanılır [9]. Bu nedenle dokuda tümör tanı ve tiplendirmesini yapmak önemli rol oynamaktadır [16]. Histopatolojik tanı için güvenilir bir yöntemdir ve immünohistokimya tayini yapmak için yeterli materyal sağladığı için İiAB'sine göre avantaj sağlar $[17,18]$. Bununla birlikte, TíB'deki daha küçük örnek boyutu, heterojen bir tümörüzerinde örnekleme hatası, ezilme veya kenar artefaktları nedeniyle TíB'sinin eksizyonel biyopsiden daha az güvenilir olabileceği endişesi olabilir. TỉB'den elde edilen ER, PgR ve HER2 gibi belirteçlerin ekspresyonu terapötik planlamaya rehberlik edeceğinden bazı durumlarda (örneğin neoadjuvan kemoterapide), daha önce mevcut olan tek veridir [4].

Meme karsinoması tanısı için TíB doğruluğu kapsamlı bir şekilde araştırılmış ve TíB ile rezeksiyon materyali arasında \%96-\%100 arasında özgüllük oranıyla iyi uyum (\%96-\%100) bulunmuştur [19, 20]. TíB ile elde edilen lezyonun histolojik tipi, eksizyon materyali ile 87/105 (\%83) oranında uyumlu olduğu bildirilmiştir
[21]. Bizim çalışmamızda TíB ile rezeksiyon materyalleri arasında lezyonların histolojik tipi arasındaki uyuma baktığımızda uyum oranı $\% 93,75$ bulunmuştur. İnvaziv duktal karsinom olarak da bilinen özel tip olmayan invaziv meme karsinomu (NST), meme kanserinin en yaygın histolojik tipi olup, invaziv meme kanserlerinin $\% 70$ ile \%85'ini oluşturmaktadır [22]. Bizim çalışmamızda hastaların \%79,4'ü literatür verileri ile uyumlu olarak özel tip olmayan invaziv meme karsinomu tanısı almıştır.

Tümör derecesi invaziv meme kanserlerinde prognostik açıdan önem taşımakta olup, tümör derecesi yükseldikçe diferansiyasyon azalmakta ve nüksler artmaktadır [23]. Bizim çalışmamızda, tümör derecelerine baktığımızda $40(\% 63,5)$ olguda derece 2 öne çıkmakta olup, derece 1 'in olarak tanı verilen $10(\% 15,9)$ olgu ile daha az olduğu görülmüştür. HER2 aşırı eksprese ve üçlü negatif gruplarda derece 3 oranı, lüminal A ve lüminal B'ye göre daha fazla bulunmuştur.

ER, PgR, HER2 ve Ki-67 meme kanserinde en önemli prognostik ve prediktif immünohistokimyasal belirteçlerdir [24]. Bu reseptörlerin sonuçları, doku işleme, soğuk iskemi süresi, fiksasyonun yeterliliği ve İHK test tekniği gibi çeşitli faktörlerden etkilenir. TỉB'lerde soğuk iskemi süresinin nerdeyse sıfır olduğu ve boyutu küçük olduğu için daha iyi fikse olduğu düşünülür [25]. Genel olarak, literatürde TiB ve rezeksiyon materyali arasındaki uyum oranının 
ER için PgR'den daha yüksek olduğunu öne sürülmektedir. Meme rezeksiyon ile TỉB'ler arasında uyum oranı ER için \%61'den \%99'a, PgR için \%61'den \%91'e kadar değişen oranlarda görülmüştür [26]. Arnedos ve ark.'nın [4] 336 olguluk serisinde, ER için \%98,4 duyarlılık ve $\% 97,5$ özgüllük ile iyi bir korelasyon $(\% 98,2)$ bulmuşlardır. PgR için, TíB ve rezeksiyon materyali arasındaki korelasyon \%85'tir. PgR'deki uyumsuzluğun nedenine baktığımızda, PgR'nin tümör içinde daha heterojen dağılma eğiliminde olduğu düşünülmektedir [4]. Bizim olgularımızda da ER'de uyum oranı \%89, PgR'de uyum oranı \%81'dir. Rezeksiyon materyali ile karşılaştırıldığında TỉB'de yüksek puanlama eğilimi de tarif edilmiştir. Bu bulgu, trucut biyopsi örneklerinde cerrahi örneğe kıyasla daha iyi fikse olmasına bağlanmıştır. ER'de 7 olguda, PgR'de 12 olguda uyumsuzluk görülmüştür. ER için, TíB'de pozitif olan 5 olgu, rezeksiyon materyalinde negatif olarak değerlendirilmiştir. ER \%1-10 arasında olan 2 olgu rezeksiyon materyalinde $>\% 10$ 'dur. TíB'de negatif olup rezeksiyon materyalinde pozitif olan olgu yoktur. Bu da TíB'de daha iyi fiksasyona bağlı, daha yüksek skorlama eğilimini desteklemektedir. Ancak bu durum PgR'de geçerli değildir. PgR'de ise TỉB'de pozitif 4 olgu, rezeksiyonda negatif bulunmuş olup, TỉB'de negatif 8 olgu rezeksiyonda pozitif bulunmuştur. $\mathrm{Bu}$ durum da PgR'nin heterojen dağılımını destekler niteliktedir. Meme kanserleri genomik ve transkriptomik olarak heterojen tümörlerdir [27]. Greer ve ark.'nın [28] çalışmasında, tümör heterojenitesinin daha büyük boyutlu tümörlerde (ortalama boyut $4,5 \mathrm{~cm}$ ) ve multifokal veya multisentrik hastalığı olan hastalarda daha yaygın olduğunu bulmuşlardır.

HER2 pozitif meme kanseri hastalarının TíB ile belirlenmesi önemlidir [9]. Aşırı HER2 ekspresyonu olan hastalar, kemoterapi ile kombine edildiğinde hastalıksız sağkalımı ve genel sağkalımı önemli ölçüde iyileştirdiği gösterilen anti-HER2 tedavisinden faydalanabilir [28]. HER2 tayini için, sonuçların iyi bir uyum oranı gösterdiği görülmüştür [4]. Önceki çalışmalarda meme rezeksiyon ile TíB'ler arasında HER2 için \%64'den \%96'ya kadar değişen uyum oranı görülmüştür [26]. Bizim çalışmamızda da meme rezeksiyon ile TİB'ler arasındaki HER2 için uyum oranı \%95'dir. Uyum çok iyi olup, kappa, 0,868, $p<0,001$ 'dir. HER2 uyum oranı HR, ER ve PgR reseptör uyum oranına göre daha iyidir. TIBB ve rezeksiyon materyali arasında HER2 ile 3 olguda uyumsuzluk görülmüştür. TỉB'de skor 0 olan olgu rezeksiyon materyalinde skor 2 (FiSH+), skor 2 olan 2 olgudan 1'i rezeksiyonda skor 1 (FISH+), 1'i de skor 3 (FiSH-) bulunmuştur.

Ki-67, kanserde yaygın olarak kullanılan bir hücre proliferasyon belirtecidir ve bir meta-analiz, yüksek Ki-67 ekspresyonunun hastaların sonucunu olumsuz yönde etkilediğini göstermiştir. Ayrıca ER-pozitif, nod-negatif meme kanserlerini hasta tedavisine rehberlik etme potansiyeli olan prognostik alt gruplara ayırmak için de kullanılır [29]. Meattini va ark.'nın [29] çalışmasında TỉB ile meme rezeksiyon materyali arasında ile arasındaki $\% 88,1$ 'lik bir uyum oranı görülmüştür $(k, 0,68)$. Bizim çalışmamızda uyum oranı \%79 (kappa, 0,447, $p<0,001)$ görülmüştür. 13 olguda uyumsuzluk görülmüş olup, TíB'de 6 olgu $<\% 20$ bulunurken, rezeksiyon materyalinde bu olgular $\geq \% 20$ 'dir. TíB'de 7 olgu $\geq \% 20$ iken, rezeksiyon materyalinde bu olgular <\%20'dir. Bu Ki-67 ekspresyon farkının olası bir açıklaması, tümör heterojenitesi ile ilgili olabilir.

Moleküler alt tiplemede en sık olarak luminal A'nın gözlendiği bildirilmektedir. HER2 aşırı eksprese ve üçlü negatif alt tiplerinin ise daha kötü klinik sonuçlara sahip olduğu bildirilmektedir [30, 31]. Bizim çalışmamızda moleküler alt tiplerin görülme sıklığı rezeksiyon materyallerinde lüminal $A \% 65,6$, lüminal $B$ $\% 15,6$, HER2 aşırı eksprese $\% 6,3$, üçlü negatif $\% 12,5$ 'tir. Lüminal $\mathrm{A}$ en fazla görülen tip olup, uyum oranı \%97'tür. Uyum oranı lüminal B'de $\% 76$, HER2 aşırı eksprese grupta \%100, üçlü negatif grupta \%100'dür. Jeong ve ark.'nın [9] çalışmasında luminal $A$, luminal $B$, HER2 ve üçlü negatif için TỉB'li cerrahi numunelerin rezeksiyon materyallerinde sırasıyla uyum oranı $\% 89,0, \% 70,0, \% 82,9$ ve $\% 77,2$ (kappa, 0,672; iyi uyum)'dir.

Luminal A, HER2 aşırı eksprese ve üçlü negatif gruplar arasında çok iyi düzeyde uyum görüldü, ancak luminal $B$, moleküler alt tipler arasında en düşük uyum oranı gösterdi. Luminal $B$, luminal $B / H E R 2$ negatif ve luminal B/HER2 pozitif olarak alt gruplara ayrıldığında, TíB ile rezeksiyon materyali arasında 3 olgudaki uyumsuzluğun nedeni, 2 olguda Ki67 oranındaki farklılık, 1 olguda HR'lerin farklı olmasından kaynaklanmaktadır. 
Cerrahi rezeksiyon örneklerine ve daha büyük numunelere özgü fiksasyon hataları nedeniyle TiB'de, ER, PgR ve HER2 reseptör durumu daha iyi tahmin edilmektedir [25]. Ancak meme kanseri tümörlerinde immünohistokimya biyobelirteçlerinin heterojen ekspresyonu, TíB'nin tüm hastalarda gerçek biyolojik profili yeterince temsil etmeyebileceği endişesini ortaya çıkarmaktadır. Hastaların çoğunda tümör tipi, ER ve PgR açısından TiB ve rezeksiyon materyali arasında iyi bir uyum vardır. Bununla birlikte, HER2 aktivitesi, heterojen tümörlü hastalarda TíB'de yeterince tespit edilmiyor gibi görünmektedir. Heterojen tümörlere sahip olma riski nedeniyle rezeksiyon materyalinde ER, $\mathrm{PgR}, \mathrm{HER} 2$ ve Ki-67'nin yeniden test edilmesini önerilmektedir [28]. Çalışmamızın kısıtııı̆ı, aynı kişilere ait TiB ve rezeksiyon materyali olması gerektiği için, olgu sayısının az olmasıdır. Daha geniş serilerle desteklenmesi daha objektif verilerin ortaya konmasını sağlayacaktır.

Sonuç olarak, tanısal biyopsi ve rezeksiyon materyalleri arasında yüksek oranda uyum görülmüştür. Tümörün histopatolojik özelliklerinin belirlenmesi, tanı, tedavi ve prognozda önemi olan ER, PgR, HER2, Ki-67 immünhistokimyasal boyamalarının çalışııması için güvenilir materyaller olduğu sonucuna varılmıştır. Ayrıca Ki-67'nin, HER2 negatif tümörlerin moleküler subtiplemesinde önemli olduğu görülmüştür. Tümör heterojenitesinden dolayı rezeksiyon materyallerinde de ER, PgR, HER2, Ki-67 immünhistokimyasal boyamalarının çalışımasının gerekliliği ortaya konmuştur.

Çıkar ilişkisi: Yazarların çıkar çatışması bulunmamaktadır.

\section{Kaynaklar}

1. Al Thoubaity FK. Molecular classification of breast cancer: a retrospective cohort study. Ann Med Surg (Lond) 2019;49:44-48. https://doi.org/10.1016/j. amsu.2019.11.021

2. Bray F, Ferlay J, Soerjomataram I, Siegel RL, Torre LA, Jemal A. Global cancer statistics 2018: GLOBOCAN estimates of incidence and mortality worldwide for 36 cancers in 185 countries. CA Cancer J Clin 2018;68:394-424. https://doi.org/10.3322/caac.21492

3. Devrim T, Aydemir M. Comparison of hormone receptors (Er/Pgr) and Her2 values in breast cancer biopsy and resection materials. Med J SDU 2020;27:154-159. https://doi.org/10.17343/sdutfd.598845
4. Arnedos M, Nerurkar A, Osin P, A'Hern R, Smith IE, Dowsett $M$. Discordance between core needle biopsy (CNB) and excisional biopsy (EB) for estrogen receptor (ER), progesterone receptor (PgR) and HER2 status in early breast cancer (EBC). Ann Oncol 2009;20:19481952. https://doi.org/10.1093/annonc/mdp234

5. Senkus E, Kyriakides S, Ohno S, et al. Primary breast cancer: ESMO Clinical Practice Guidelines for diagnosis, treatment and follow-up. Ann Oncol 2015;26:8-30. https://doi.org/10.1093/annonc/mdv298

6. Pettine S, Place R, Babu S, Williard W, Kim D, Carter $\mathrm{P}$. Stereotactic breast biopsy is accurate, minimally, invasive, and cost effective. Am J Surg 1996;171:474476. https://doi.org/10.1016/S0002-9610(96)00007-4

7. Pijnappel RM, van Dalen A, Borel Rinkes IH, et al. The diagnostic accuracy of core biopsy in palpable and non-palpable breast lesions. Eur J Radiol 1997;24:120123. https://doi.org/10.1016/s0720-048x(96)01140-0

8. Tamaki K, Sasano H, Ishida T, et al. Comparison of core needle biopsy (CNB) and surgical specimens for accurate preoperative evaluation of $\mathrm{ER}, \mathrm{PgR}$ and HER2 status of breast cancer patients. Cancer Sci 2010;101:2074-2079. https://doi.org/10.1111/j.13497006.2010.01630.x

9. Jeong YS, Kang J, Lee J, Yoo TK, Kim SH, Lee A. Analysis of the molecular subtypes of preoperative core needle biopsy and surgical specimens in invasive breast cancer. J Pathol Transl Med 2020;54:87-94. https://doi.org/10.4132/jptm.2019.10.14

10. Buck $A$, Schirrmeister $H$, Kühn T, et al. FDG uptake in breast cancer: correlation with biological and clinical prognostic parameters. Eur J Nucl Med 2002;29:13171323. https://doi.org/10.1007/s00259-002-0880-8

11. Zhang J, Jia Z, Zhou M, et al. The SUVmax for 18 F-FDG correlates with molecular subtype and survival of previously untreated metastatic breast cancer. Clin Nucl Med 2013;38:256-262.

12. Lakhani SR, Ellis IO, Schnitt SJ, et al. eds. World Health Organization classification of tumours of the breast. 5th ed. Lyon: IARC Press, 2019;19-20.

13. Hoda SA, Brogi E, Koerner FC, Rosen PP. Rosen's breast pathology, 4rd ed. Philadelphia, PA, USA: Lippincott Williams\&Wilkins, 2014:429-430.

14. Wolff AC, Hammond ME, Allison $\mathrm{KH}$, et al. Human epidermal growth factor receptor 2 testing in breast cancer: American Society of Clinical Oncology/College of American Pathologists Clinical Practice Guideline Focused Update. J Clin Oncol 2018;36:2105-2122. https://doi.org/10.1200/JCO.2018.77.8738

15. Goldhirsch A, Winer EP, Coates AS, et al. Panel members. Personalizing the treatment of women with early breast cancer: highlights of the St Gallen International Expert Consensus on the Primary Therapy of Early Breast Cancer 2013. Ann Oncol 2013;24:22062223. https://doi.org/10.1093/annonc/mdt303 
16. Shannon J, Douglas Jones AG, Dallimore NS. Conversion to core biopsy in preoperative diagnosis of breast lesions. Is it justified by the results? J Clin Pathol 2001;54:762-765. https://doi.org/10.1136/ jcp.54.10.762

17. Pettine S, Place R, Babu S, et al. Stereotactic breast biopsy is accurate, minimally invasive, and cost effective. Am J Surg 1996;171:474-476.

18. Pijnappel RM, van Dalen A, Borel Rinkes IH, et al. The diagnostic accuracy of core biopsy in palpable and non-palpable breast lesions. Eur J Radiol 1997;24:120123. https://doi.org/10.1016/s0720-048x(96)01140-0

19. Verkooijen HM, Peeters PH, Buskens E, et al. Diagnostic accuracy of large-core needle biopsy for nonpalpable breast disease: a meta-analysis. $\mathrm{Br} \mathrm{J}$ Cancer 2000;82:1017-1021. https://doi.org/10.1054/ bjoc.1999.1036

20. Dillon MF, Hill AD, Quinn CM, O'Doherty A, McDermott EW, O'Higgins $N$. The accuracy of ultrasound, stereotactic, and clinical core biopsies in the diagnosis of breast cancer, with an analysis of false negative cases. Ann Surg 2005;242:701-707. https://doi. org/10.1097/01.sla.0000186186.05971.e0

21. Usami S, Moriya T, Amari M, et al. Reliability of prognostic factors in breast carcinoma determined by core needle biopsy. Jpn J Clin Oncol 2007;37:250-255. https://doi.org/10.1093/jjco/hym021

22. Alkabban FM, Ferguson T. Cancer, Breast. In: StatPearls. Treasure Island (FL). Available from: https:// www.ncbi.nlm.nih.gov/books/NBK482286/. Accessed Jun 4, 2019

23. Yersal O, Barutca S. Biological subtypes of breast cancer: prognostic and therapeutic implications. World J Clin Oncol 2014;5:412-424. https://doi.org/10.5306/ wjco.v5.i3.412

24. Kunc M, Biernat W, Senkus Konefka E. Estrogen receptor-negative progesterone receptor-positive breast cancer- "Nobody's land" or just an artifact? Cancer Treat Rev 2018;67:78-87. https://doi. org/10.1016/j.ctrv.2018.05.005

25. Damodaran D, Naidu BK, Varghese JC, et al. A prospective study on level of concordance between core needle biopsy and surgical specimen for assessing oestrogen receptor, progesterone receptor, and Her2/neu receptor status in carcinoma breast and lits limplications on Ttreatment Ddecisions. Indian J Surg Oncol 2020;11:446-450. https://doi.org/10.1007/ s13193-020-01146-y2020

26. Asogan AB, Hong GS, Arni Prabhakaran SK. Concordance between core needle biopsy and surgical specimen for oestrogen receptor, progesterone receptor and human epidermal growth factor receptor 2 status in breast cancer. Singapore Med J 2017;58:145149. https://doi.org/10.11622/smedj.2016062
27. Walter V, Fischer C, Deutsch TM, et al. Estrogen, progesterone, and human epidermal growth factor receptor 2 discordance between primary and metastatic breast cancer. Breast Cancer Res Treat 2020;183:137144. https://doi.org/10.1007/s10549-020-05746-8

28. Greer LT, Rosman M, Mylander WC, et al. Does breast tumor heterogeneity necessitate further immunohistochemical staining on surgical specimens? J Am Coll Surg 2013;216:239-251. https://doi. org/10.1016/j.jamcollsurg.2012.09.007

29. Meattini I, Bicchierai G, Saieva C, et al. Impact of molecular subtypes classification concordance between preoperative core needle biopsy and surgical specimen on early breast cancer management: single-institution experience and review of published literature. Eur J Surg Oncol 2017;43:642-648. https:// doi.org/10.1016/j.ejso.2016.10.025

30. Kondov B, Milenkovikj Z, Kondov G, et al. Presentation of the molecular subtypes of breast cancer detected by ımmunohistochemistry in surgically treated patients. Open Access Maced J Med Sci 2018;6:961-967. https://doi.org/10.3889/oamjms.2018.231

31. Onitilo AA, Engel JM, Greenlee RT, Mukesh BN. Breast cancer subtypes based on ER/PR and Her2 expression: comparison of clinicopathologic features and survival. Clin Med Res 2009;7:4-13. https://doi. org/10.3121/cmr.2009.825

Etik kurul onayı: Bu çalışmanın etik kurulu, Pamukkale Üniversitesi Girişimsel Olmayan Klinik Araştırmalar Etik Kurulu tarafından 19.10.2020 tarih ve 63657 sayılı toplantıda kabul edilmiştir.

\section{Yazarların makaleye olan katkıları}

Makalenin Anafikri: Y.A.K.

Literatür taranması: Y.A.K., S.Y.

Veri toplama: H.K., Y.A.K., S.Y.

İstatistiğin yapılması: Y.A.K.

Makalenin yazılması: Y.A.K., S.Y. 